\title{
Emerging and re-emerging biotic stresses of agricultural crops in India and novel tools for their better management
}

\author{
J. Kumar*, R. K. Murali-Baskaran, S. K. Jain, P. N. Sivalingam, J. Mallikarjuna, Vinay Kumar, \\ K. C. Sharma, J. Sridhar, P. Mooventhan, A. Dixit and P. K. Ghosh
}

Food security of our country is at risk due to heavy yield losses of agricultural crops caused by pests and diseases known together as biotic stresses. Conventional management practices in vogue are not competent under the current situations obscured by the incitants of biotic stresses which have either enhanced their offensive capabilities due to adaptive mutations or regained their pathogenic/herbivory potential owing to climate change. Numerous causal agents of biotic stresses are also introduced in the country or new regions of the country either through natural dispersal as invasive species, or on account of quarantine irregularities at national or international levels. Therefore, it is of utmost importance to appraise the impact of these new biotic stresses burgeoned in the recent past and to develop novel technologies for their management. To devise an effective preventive and eradicative strategy for containing these biotic stresses, new research innovations need to be practiced such as deciphering basic/molecular mechanism of host-pathogen/insect interactions; endophytic mechanisms of plant protection; nanotechnology in pest management; host resistance strengthening by gene cloning, recombinant DNA technologies, RNA biology, utilizing gene editing technologies such as CRISPR/Cas9, etc. This article presents a comprehensive account of new biotic stresses of agricultural crops built up in the country and also reviews the novel scientific inventions made worldwide which can be further employed to devise more efficient methods for alleviating impact of these biotic stresses of food crops in the country.

Keywords: Agriculture, biotic stress, crops, food security, management.

ANNUAL yield of agricultural crops are lost to the tune of $30-35 \%$ in India due to attack of various pests and diseases or biotic stresses ${ }^{1}$. Of late, upsurges of several new stresses have also been noted. Several factors are responsible for build up of biotic stresses such as shift of secondary causal agents to primary status, injudicious use of pesticides, climate change, resistant pest populations, invasive pests, biotype development, human interventions, etc. As an overhaul of this pitfall, there is a necessity to re-look the basic information of biology and ecology of these biotic stresses, molecular basis of their identification and interaction between causal agents and their hosts, fine tuning of existing mitigation practices and/or formulation of novel ecologically viable management strategies. Build up of biotic stresses in nature is a continuous process, particularly in favourable environments. Environmental aberrations often may cause emergence of

The authors are in the ICAR-National Institute of Biotic Stress Management, Raipur 493 225, India.

*For correspondence. (e-mail: moola01@yahoo.com) new pathogenic races/biotypes. Pathogens and insect pests prevailing with minor status acquire major proportion due to enhanced adaptation capabilities owing to mutational changes for survival. The agricultural crops are also vulnerable to threats from exotic pests/pathogens/ weeds which may get purposefully or accidentally introduced to the country or new areas in the country in addition to natural dispersal. Insect pests and other pathogens of important crops in India built up in the recent times under the influence of climate change, mutational changes for survival, acquired resistance to pesticides, transboundary invasions, etc. are shown in Tables 1 and 2. A brief account of these biotic stresses is reviewed below.

\section{Insects}

Emerging insect pests

A pest reported from an area on a particular crop showing considerable increase in its population and potential to 
GENERAL ARTICLES

Table 1. Pests and diseases of agricultural crops emerged in India as consequences of climate change

\begin{tabular}{|c|c|c|}
\hline Crop & Insect pests & Diseases \\
\hline \multicolumn{3}{|l|}{ Cereals } \\
\hline Rice & $\begin{array}{l}\text { Swarming caterpillar (Spodoptera mauritia })^{1}, \text { Gallmidge } \\
\quad(\text { Orseolia oryzae Wood-Mason })^{81}, \text { Brown plant hopper } \\
(\text { Nilaparvata lugens })^{82}\end{array}$ & $\begin{array}{l}\text { Sheath blight (Rhizoctonia solani) and } \\
\text { False smut of rice (Ustilaginoides } \\
\text { virens), Bakane (Fusarium oxysporum } \\
\text { f. sp. fujikuroi) })^{82}\end{array}$ \\
\hline Wheat & $\begin{array}{l}\text { Pink stem borer (Sesamia inference Walker) }{ }^{5} \text {, Sugarcane } \\
\text { pyrilla (Pyrilla perpusilla Walker) }{ }^{6} \text {, Aphid complex: } \\
\text { (Sitobion avenae F.), Rhopalosiphum maidis (Fitch), } \\
\text { Schizaphis graminum (Raandani) }{ }^{83}\end{array}$ & $\begin{array}{l}\text { Rice blast (Pyricularia oryzae var. } \\
\left.\text { triticum })^{24,84} \text { Black rust (UG } 99\right)- \text { a } \\
\text { potential looming threat to India, yellow } \\
\text { rust pathotypes } 46 \mathrm{~S} 119 \& 238 \mathrm{~S} 119 \\
\text { (ref. } 25 \text { ) }\end{array}$ \\
\hline Maize & Fall armyworm (Spodoptera frugiperda J. E. Smith) ${ }^{85}$ & - \\
\hline \multicolumn{3}{|l|}{ Pulses } \\
\hline Chickpea & Blister beetle (Mylabris pustulata $)^{5}$ & $\begin{array}{l}\text { Dry root rot }(\text { Rhizoctonia bataticola })^{82} \\
\text { and collar rot of chickpea } \\
(\text { Sclerotium rolfsii })^{86}\end{array}$ \\
\hline Cowpea & Spotted pod borer (Maruca vitrata Geyer) ${ }^{82}$ & - \\
\hline Mung bean/Urd bean & $\begin{array}{l}\text { White fly (Bemisia tabaci): not a concern but the mosaic virus } \\
\text { vectored by it causes severe disease and reduction in crop } \\
\text { yield }^{82}\end{array}$ & Stem blight (Stemphyllium botryosum $)^{82}$ \\
\hline Pigeon pea & Spotted pod borer (Maruca vitrata) $)^{82}$ & Phytophthora stem blight of pigeon pea ${ }^{82}$ \\
\hline \multicolumn{3}{|l|}{ Fruits } \\
\hline Mango & $\begin{array}{l}\text { Fruit fly (Bactrocera dorsalis Hendel })^{87} \text {, Leafminer } \\
\qquad(\text { Acrocercops syngramma } \text { Meyrick) })^{88} \text {, Fruit borer } \\
\quad(\text { Autocharis albizonalis and Tirathaba mundella })^{82}\end{array}$ & Wilt (Vector borne Ceratocystis) ${ }^{82}$ \\
\hline Apple & - & Leaf spot (Marssonina coronaria) $)^{82}$ \\
\hline Guava & Spiralling whitefly (Aleurodicus disperses Russell) ${ }^{89}$ & - \\
\hline Sapota & Seed borer (Trymalitis margarius Meyrick) ${ }^{90}$ & - \\
\hline Citrus & Fruit sucking moth (Otheris fullonica Clerck), $(\text { O. ancilla })^{91}$ & - \\
\hline Grapevine & Shield bug (Scutellera perplexa F. $)^{92}$ & Rust (Phakospora euvitis) $)^{82}$ \\
\hline Pomegranate & Tea mosquito bug (Helopeltis antonii Stonedahl) ${ }^{93}$ & $\begin{array}{l}\text { Bacterial leaf spot (Xanthomonas } \\
\text { axonopodis pv punicae) }\end{array}$ \\
\hline Banana & Skipper (Erionata torus Evans) ${ }^{94}$ & $\begin{array}{l}\text { Wilt TR } 4 \text { (Fusarium oxysporum } \mathrm{f} . \mathrm{sp} \\
\text { cubense TR } 4)^{82}\end{array}$ \\
\hline Litchi & Fruit borer (Conopomorpha sinensis Bradley) ${ }^{95}$ & - \\
\hline Coconut & White fly (Aleurodicus rugioperculatus) ${ }^{82}$ & \\
\hline Arecanut & White grub (Holotrichia consanguinea) ${ }^{82}$ & - \\
\hline \multicolumn{3}{|l|}{ Vegetables } \\
\hline Brinjal & Mealybug (Phenococcus solenopsis Tinsley) ${ }^{96}$ & - \\
\hline Tomato & Mealybug (Phenococcus solenopsis Tinsley) ${ }^{96}$ & Tomato spotted wilt virus ${ }^{82}$ \\
\hline Okra & Mealybug (Phenococcus solenopsis Tinsley) ${ }^{96}$ & - \\
\hline Chilli & $\begin{array}{l}\text { Gall midge (Asphondylia capparis Rubsaman })^{96} \text {, White fly } \\
\text { (Bemisia tabaci) and Aphids (Aphis gossypii), } \\
\text { Capsicum also }^{82}\end{array}$ & - \\
\hline Onion and garlic & Army worm (Spodoptera exigua Hubner $)^{96}$ & - \\
\hline Cowpea & Spotted pod borer (Maruca vitrata Geyer) ${ }^{4}$ & - \\
\hline Bottle gourd & Mirid bug (Nesidiocoris cruentatus Ballard) ${ }^{97}$ & - \\
\hline Cucurbits & Red spotted mite (Tetranychus urticae Koch) ${ }^{98}$ & - \\
\hline \multicolumn{3}{|c|}{ Commercial and ornamentals } \\
\hline \multirow[t]{3}{*}{ Cotton } & Green ired bug (Creontiades biseratense Distant) ${ }^{1}$ & - \\
\hline & Mealybug (Phenococcus solenopsis Tinsley) ${ }^{99}$ & - \\
\hline & Whitefly (Bemesia tabaci Gennadius) $)^{23}$ & - \\
\hline \multicolumn{3}{|c|}{ Protected cultivation (due to conserved temperature, humidity and diffused light) } \\
\hline Tomato & White fly (Bemisia tabaci) $)^{82}$ & $\begin{array}{l}\text { Leaf curl virus, Root knot nematode } \\
\qquad(\text { Meloidogyne incognita } \text { Race } 1)^{82}\end{array}$ \\
\hline Cucumber & $\begin{array}{l}\text { Cucumber mosaic virus, Spidermites (Tetranychus urticae), } \\
\text { White fly (Bemisia tabaci) })^{82}\end{array}$ & Fusarium wilt (Fusarium oxysporum $)^{82}$ \\
\hline Capsicum & $\begin{array}{l}\text { Thrips (Scirtothrips dorsalis), spidermites (Tetranychus } \\
\text { urticae) }\end{array}$ & - \\
\hline
\end{tabular}


GENERAL ARTICLES

Table 2. Pests and diseases of agricultural crops built up in India as consequences of invasion

\begin{tabular}{|c|c|c|}
\hline Crop & Pest & Diseases \\
\hline \multicolumn{3}{|l|}{ Cereals } \\
\hline Maize & Fall armyworm (Spodoptera frugiperda J.E. Smith) ${ }^{100}$ & - \\
\hline Wheat & - & $\operatorname{Yr} 9$ pathotype of yellow rust of wheat ${ }^{101}$ \\
\hline \multicolumn{3}{|l|}{ Fruits } \\
\hline Apple & Wooly apple aphid (Eriosoma lanigerum) $)^{102}$ & - \\
\hline Papaya & $\begin{array}{l}\text { Mealybug (Paracoccus marginatus Williams and } \\
\text { Granara de Willink) }{ }^{103} \text { introduced from USA (CS) }\end{array}$ & - \\
\hline Banana & - & $\begin{array}{l}\text { Banana wilt (Fusarium oxysporum f. sp. } \\
\text { cubense tropical race } 4 \text { (Foc TR } 4)^{27}\end{array}$ \\
\hline Coconut & $\begin{array}{l}\text { White fly (Aleurodicus rugioperculatus) })^{82}, \text { Paraleyrodes } \\
\text { minei }^{104}\end{array}$ & - \\
\hline \multicolumn{3}{|l|}{ Vegetables } \\
\hline Potato & Tuber moth (Phthorimaea operculella Zeller) ${ }^{105}$ & - \\
\hline Cabbage & Diamondback moth (Plutella xylostella Linn.) ${ }^{106}$ & - \\
\hline Tomato & Leaf miner (Tuta absoluta $)^{107}$ & - \\
\hline Chilli & Western flower thrips (Frankliniella occidentalis Pergande) ${ }^{108}$ & - \\
\hline Onion & Thrips palmi & - \\
\hline Many vegetable crops & Serpentine leaf miner (Liriomyza trifolii Burges) ${ }^{109}$ & - \\
\hline Many vegetable crops & Silver leaf whitefly (Bemisia argentifolii Bellows) ${ }^{105}$ & - \\
\hline \multicolumn{3}{|l|}{ Horticultural crops } \\
\hline Papaya & & Papaya ringspot virus strain PRSV-P ${ }^{87}$ \\
\hline Several crops & Spiraling whitefly (Aleurodicus disperses Russell) ${ }^{110}$ & - \\
\hline \multicolumn{3}{|c|}{ Commercial and ornamentals } \\
\hline \multirow[t]{3}{*}{ Coconut } & Eriophid mite (Aceria gurreronis Keifer Singh) $)^{105}$ & - \\
\hline & $\begin{array}{l}\text { Rugose spiraling whitefly (Aleurodicus rugioperculatus } \\
\text { Martin) }\end{array}$ & - \\
\hline & $\begin{array}{l}\text { Neotropic whitefly (Aleurotrachelus atratus Hempel) }{ }^{112} \text {, } \\
\text { Paraleyrodes minei }{ }^{104}\end{array}$ & - \\
\hline Cotton & Mealybug (Phenococcus solenopsis Tinsley) $)^{113}$ & - \\
\hline Coffee & Berry borer (Hypothenemus hampei Ferrari) ${ }^{114}$ & - \\
\hline
\end{tabular}

cause economic damage over a period of time is termed as emerging insect pest ${ }^{2}$. Sucking insect pests, mirid bug, mealybug, whitefly, aphids and plant hoppers on major crops; Helicoverpa armigera on vegetables and pulses; Spodoptera litura on vegetables, cotton and oilseeds; Pieris brassicae on crucifers; Liriomyza trifolii on vegetables; Atherigona spp. on spring maize; aphid complex like Sitobion avenae, Rhopalosiphum maidis and Schizaphis graminum on wheat, barley and oat; green mirid bug, Creontiades biseratense on cotton in states such as Karnataka, Tamil Nadu, Maharashtra, Andhra Pradesh; eriophyiid and tetranychid mites on bean, brinjal, cotton, cucurbits, okra, apple, ber, citrus, mango in North India, Maruca vitrata on pigeonpea and cowpea in Andhra Pradesh, sugarcane pyrilla on wheat and oat in Chhattisgarh, etc. have been reported to emerge in India ${ }^{3-6}$. The possible reasons for the emergence of insect pests are climate change, physiological and ecological impacts, change in feeding habit of herbivory, increased overwintering survival, increased number of generations of pest, breakdown of host resistance, change of genotypes/ impact of transgenics, injudicious use of pesticides, modification of cultural practices/tillage, etc. A noteworthy instance in this context has been that of 11 genetic groups of whitefly (Bemisia tabaci) reported to emerge in India out of a total of 42 in the world. These genetic groups have differed in their ability to transmit begomoviruses and on many occasions this became a reason for the emergence of begomoviral disease epidemics ${ }^{7}$.

\section{Invasive insect pests}

Invasive insect species cause huge economic losses and their threat is on continuous rise in the areas of Indian agricultural biodiversity, livelihoods, human and animal health, forestry and biodiversity ${ }^{8}$. Since 1889 , a total of 24 insect species have been reported to invade India ${ }^{9,10}$. India witnessed its first ever invasive insect pest San Jose scale (Quadaraspidiotus perniciosus Comstock) in 1879 from China. As on 2019, the tally rose to a total of 23 insect pest species and since 1879 they are affecting the agro-ecological balance of the country and causing huge economic loss over the years. Tomato leaf miner (Tuta absoluta Meyrick) has become the most destructive major nocturnal pest of tomato production as well as other 
solanaceous crops due to its invasions in different parts of the world ${ }^{11}$. Since it originated in South America, it is known as South American tomato moth, tomato borer or American tomato pinworm ${ }^{12}$. It is also reported to attack potato, eggplant, hot pepper, some weeds (Datura stramonium and Nicotiana glauca) and some other nonsolanaceous crop plants like green beans or Malva spp ${ }^{13}$. Melon thrips (Thrips palmi Karny) is a polyphagous pest with wide host range including Solanaceae, Cucurbitaceae and Leguminosae plants in tropical and subtropical countries $^{14}$. Another notorious invasive pest, the fall armyworm (Spodoptera frugiperda) was first noticed at Shivamogga, Karnataka during May 2018 (ref. 15). This has been spreading fast into new territories in the states of Karnataka, Telangana, Andhra Pradesh, Maharashtra, Gujarat and Tamil Nadu ${ }^{15}$.

\section{Climate change impacts on insect pests}

Climate change is another important issue to determine the status of insect pests in India. Changed patterns in climatic factors like temperature, precipitation, humidity and other meteorological parameters affect the biology and ecology of insect pests and increase their population. The damage potential of pests ameliorated by their expanded distribution, enhanced survivability and adaptability, alteration in tri-trophic interaction, emergence of new biotypes, etc. in turn, increased the yield losses further by $10-25 \%$ (ref. 16). A study revealed that the number of eggs laid by yellow stem borer (YSB) increased at higher temperatures while egg hatching was reduced leading to a lesser survival of YSB with increased temperature ${ }^{17}$. Temperature below or above the range of $27^{\circ}-$ $30^{\circ} \mathrm{C}$ limited the survival and development of Spodoptera litura on peanut. The life patterns of $S$. litura were also significantly affected by higher rate of $\mathrm{CO}_{2}$ (ref. 18). Elevated temperature and $\mathrm{CO}_{2}$ significantly increased the reproductive time of aphids leading to production of offsprings for longer periods affecting growth and development at second trophic level in cowpea ${ }^{19}$.

\section{Pesticide induced resistant insect populations}

Evolutionary biologists are generally confounded with the process of evolution of resistance in various pest organisms against pesticides ${ }^{20}$. Several biological, genetic and operational factors affect resistance development in pest populations ${ }^{21}$. An estimated 954 pest species have developed resistance against various types of pesticides ${ }^{22}$. Once resistance to pesticides is detected, the ineffective molecules can be avoided and such information also assists in making a proper recommendation of alternative molecules that are less resisted and can effectively control insect pests. Application of pesticides that would have otherwise harmed the environment without actually having served the designated purpose of pest management can be avoided if information on resistance to that particular pesticide is determined ${ }^{23}$. Periodical monitoring and following insecticide resistance management suggested by Insecticide Resistance Action Committee (IRAC) would be useful to manage the insecticide resistant insect populations ${ }^{22}$.

\section{Plant pathogens}

\section{Burgeoning fungal pathogens of plants}

Prevalence and distribution patterns of several fungal pathogens have changed over the years. Blast of rice remains the most important fungal disease in India, however, sheath blight's (Rhizoctonia solani) severity and drastic spread and increase in almost all rice growing regions during the past few years caused major losses to the yield as well as increasing fungicidal sprays. Similarly, increased occurrence of false smut of rice has been observed in recent years ${ }^{24}$. Among other cereals, large areas under wheat are continuing to be vulnerable to yellow rust pathogen (Puccinia striiformis) which is evolving regularly rendering wheat varieties susceptible ${ }^{25}$. Stalk rot, downy mildew and leaf spots are the major constraints in maize crop in India, and sugarcane red rot with continuous emergence of variability in the pathogen is posing a threat to sugarcane yield ${ }^{26}$. The emergence of virulent Tropical race 4 (TR4) of Fusarium wilt has a devastating effect on banana cultivation in the world and has also been detected in India in the recent past with high incidence and crop damage $\mathrm{e}^{27}$. Soil-borne fungal pathogens are becoming increasingly devastating to the crops which are difficult to control. These pathogens cause heavy losses in economically valuable crops like pulses, vegetables, rice, etc. In recent years, dry root rot of chickpea (Rhizoctonia bataticola) and Phytophthora stem blight of pigeon pea (Phytophthora drechsleri f. sp. cajani) have emerged as potential threats ${ }^{28}$. Soil-borne diseases caused by fungal pathogens Phytophthora, Pythium, Rhizoctonia solani and Sclerotium rolfsii are favoured by excess soil moisture, especially in pulses ${ }^{29}$.

The inevitable climatic changes also affected the reproduction, spread and severity of fungal pathogens resulting in the increased frequency of occurrence and severity of different diseases. Climate change reduced the efficiency of many $\mathrm{Sr}$ genes in wheat which were governing resistance against Ug99 race of Puccinia graminis $\mathrm{f}$. sp. tritici. Also, elevated temperature and $\mathrm{CO}_{2}$ aggravated virulence of Phytophthora infestans causing late blight of potato, Pyricularia oryzae causing rice blast and Rhizoctonia solani causing sheath blight of rice ${ }^{30}$.

Plant health is globally endangered through introduction of exotic pathogens as consequences of increasing globalization, travel and international trade. Certain 
virulent races of fungal pathogens, viz. Ug99 group of races of wheat stem rust pathogen, wheat blast pathogen, and soybean downy mildew, though not present in India, are a serious threat to our crop production programmes if they occur in India. A severe outbreak of wheat blast in the neighbouring country Bangladesh in early 2016 had roused a serious phytosanitary concern in India $^{31}$.

\section{Emergence of new bacterial diseases}

Considerable yield losses occur in agricultural crops in India due to infection of phytopathogenic bacteria. Some of them which have emerged with significant importance are bacterial blight of rice (Xanthomonas oryzae pv ory$z a e)$, bacterial blight of pomegranate ( $X$. axonopodis pv punicae), bacterial wilt of vegetables (Ralstonia solanacearum), black spot of mango ( $X$. citri pv mangiferae indicae), and bacterial blight of cotton ( $X$. citri sub sp. malvacearum). Apart from these, panicle blight of rice (Burkholderia glumae) and stalk rot of maize (Pectobacterium chrysenthemi var. zeae) have also emerged in the recent years as potential threat to yield of respective food grains in India ${ }^{32}$.

\section{Emergence of new viral diseases}

Climate change and human population pressure also favour emergence of new viral diseases in plants ${ }^{30}$. Several viruses and their strains or isolates or their combinations caused diseases in crops especially vegetable crops due to introduction of hybrids. Recently, Tiranga disease $^{32}$ was reported from Maharashtra and the diseased samples were found to be associated with five different viruses. Rice tungro, ground nut bud necrosis, sunflower necrosis, yellow mosaic of legumes, pigeon pea sterility mosaic, soybean bud blight, cotton leaf curl, cassava mosaic, potato apical leaf curl, banana bunchy top, banana bract mosaic, papaya leaf curl, papaya ringspot, chlorotic leaf spot in peach, piper yellow mottle are some of the emerging viral diseases which have built up in the recent times $^{33}$. The incidence of papaya ringspot virus has also been recorded all over the country ${ }^{34,35}$.

\section{Emergence of new nematode diseases of plants}

Our country is also facing a plethora of nematological problems in cereals, pulses, oilseeds, vegetables, fruits, fibre and plantation crops. The root-knot nematodes belonging to the genus of Meloidogyne have gained importance and are responsible for causing severe yield losses to vegetable crops under intensive cultivation. They also became a major threat to protected cultivation of vegetables and ornamental crops. Rice root-knot nematode,
M. graminicola has established in low land rice cultivation. Pratylenchus spp. and Rotylenchulus spp. are noticed in high frequencies in important pulse and oilseed crops of the country. Guava and pomegranate crops are also facing severe threat from an invasive nematode pest, viz. M. enterolobii ${ }^{36}$.

\section{Weed problems in crops and cropping systems}

South American Asteraceae weeds such as Parthenium hysterophorus, Eupatorium adenophorum, Eupatorium odoratum, Mikania micrantha, Ageratum conyzoides, Galinsoga parviflora, Ageratum conyzoides L. have invaded and naturalized in several parts of Southern Asia including India ${ }^{37}$. Species of parasitic dodders (Cuscuta spp.) has emerged as a menace in several parts of South India and are becoming serious constraints in successful cultivation of pulses and oilseeds, throughout the country ${ }^{38,39}$.

\section{Quarantine lacunae}

From time to time, the pests and pathogens introduced from exotic sources have devastated crop yields in several parts of the country. Prior to implementation of Plant Quarantine Order 2003, woolly aphid, cottony cushion scale, golden cyst nematode of potatoes, San Jose scale, the giant African snail were introduced into India from across the border. The domestic quarantine systems and regulations are not up to the mark in our country due to the unorganized and multi-dimensional nature of the farm sector $^{40}$. Further, the pest risk analysis (PRA) procedure and quarantine regulations cannot be imposed in their true sprits in a largely populated country like India ${ }^{41}$. Recently, after ravaging cornfields of sub-Saharan Africa, the Fall Armyworm (FAW) entered India in 2018, and the infestation has already spread to most parts of the subcontinent. The severe infestation has been reported from more than 20 maize growing states of India ${ }^{10}$.

\section{Raging mammalian pests emerging as the biggest menace in farming sector}

\section{Blue bull (Nilgai)}

Among mammals, Blue bull (Boselephus tragocamelus, commonly called as Nilgai) prevails as a major pest of wild animal category in agriculture dominated landscapes in central and northern India ${ }^{42}$. Crop raiding and crop damage by Nilgai are quite often reported in agricultural fields around protected areas. To tackle the problem of Nilgai crop damage, various management interventions have been suggested and implemented. The fodder plants have been planted in the forest area for feeding Nilgai. Permanent watchers have been placed by Forest 
Department to prevent raid on agriculture crops. Many indigenous measures are employed to curb the menace of Nilgai which include use of effigy models, use of shining tapes like video or audio tapes, live fencing along with use of beating bells, animal excreta, phenyl solutions, fire crackers, forate insecticide granules, walled fencing, barbed fencing, watchers by involving local communities, etc. ${ }^{43}$.

\section{Wild boar and monkey menace}

The wild boar (Sus scrofa) and langur monkey (Semnopithecus entellus) are the widely distributed large mammals gaining pest status and have become regular menace for farmers in case of major crops ${ }^{44}$. The wild boar damages crops at all growth stages ${ }^{45,46}$. Population of wild boars increased as a result of heavy deforestation as forests are the natural habitats of these species ${ }^{47}$. The natural predators of wild boars, i.e. tigers, panthers, wild dogs, wolf and jackal also reduced owing to indiscriminate deforestation $^{48}$. Several indigenous techniques may be employed to ward off wild boars. Some of such effective ways like spraying of local pigs dung solution (up to $50 \%$ damage control), human hair as deterrent (40-50\% damage control), erection of used coloured sarees (30-55\% control), burning of dried dung cakes (35-50\%), planting of thorny bushes and xerophytes around the crop (50-70\%), creation of sounds and light through bonfire (40-60\%), and traditional use of local dogs for scaring away wild boars (up to $50 \%$ control), practiced by local people were scientifically evaluated and validated for efficiency and economic feasibility ${ }^{49}$.

\section{Novel tools for devising innovative strategies of plant protection}

Agriculture in India is witnessing rapid transition from mere sustenance to entrepreneurial commercial farming. Farmers now opt for high yielding varieties and hybrids. Yields are maximized through input intensive farming which often paves way for indiscriminate misuse of fertilizers and pesticides, making crops vulnerable to various diseases and pests. Overuse of fertilizers and pesticides also cause water and air pollution, residual toxicity in fruits and vegetables, resistance to pesticides in insects and pathogens, mortality of natural biocontrol-friendly insects, rise of secondary pests, etc. ${ }^{50}$. At this juncture, novel mitigation measures need to be contrived on priority for curtailing the huge yield losses caused by various biotic stresses of agricultural crops. In this context, various key research areas for future work include deciphering basic/molecular mechanism of host-pathogen/insect interactions, nanotechnology in pest management, fumigants, volatile and acoustic techniques for stored grains, post-harvest and vertebrate pest management, utilizing gene editing technologies such as CRISPR/Cas9, elaborated tritrophic pheromone/kairomone studies, deployment of remote sensing technology for pest management, disease/pest prediction and forecasting, determination of factors leading to evolution of pests and pathogens, development of technologies to minimize the adverse effects of climate change on biotic stresses of plants, allelopathy based weed management etc. Efforts have been made worldwide to search novel and more efficient tools for mitigating losses due to biotic stresses and a brief account of the same is presented below.

\section{Transgenic crops with insecticidal toxins}

With the advancement of molecular biology in the recent times, a new innovation of genetic engineering lure the plant scientists worldwide and so is also true with agricultural scientists as well. Plant protection scientists are now capable of manipulating the genetic material of a cell in order to produce pest resistant varieties of several crops. Genetic engineering technology has been successfully employed in developing cotton genotypes resistant to lepidopteran larvae (caterpillars) and maize genotypes resistant to both lepidopteran and coleopteran larvae (root worms) leading to reduction in pesticide usage and that of production costs ${ }^{51,52}$. The transgenic plants of these crops had $B t$ genes derived from the soil bacterium Bacillus thuringiensis $(B t)$. Genotypes with $B t$ genes show insecticidal activity toward pests, and constitute a large reservoir of genes encoding insecticidal proteins. $B t$ genes are responsible for accumulation of crystalline inclusion bodies produced by the bacterium on sporulation (Cry proteins, Cyt proteins), or expressed during bacterial growth (Vip proteins). Additional Bt Cry genes can be transgenically incorporated into the crop for achieving protection against a wider range of pests. Transgenic cotton containing two $B t$ genes was first used in 1999, three years after the release of the original single $B t$ variety. Cotton plants containing two genes corresponding to CrylAc and $\mathrm{Cry} 2 \mathrm{Ab}$ proteins respectively, showed more toxicity towards bollworms (Helicoverpa zea; target pest) and two species of armyworms (Spodoptera frugiperda and Spodoptera exigua; secondary pests), than the cotton with single gene related to Cry $1 \mathrm{Ac}^{53,54}$. Site-directed mutagenesis modifies $B t$ toxins resulting in increased toxicity towards target pests. Such an alteration due to chemical domain exchange in $B t$ genes is termed as 'domain swap' approach. The key role of domain II in threedomain Cry proteins in mediating interactions with insect receptors has been exploited by mutation of amino acid residues in the loop regions of this domain. Mutation of Cry $1 A B$ increased its toxicity towards larvae of gypsy moth (Lymantria dispar) by up to 40 folds $^{55}$. Hemipteran plant pests are not affected by known $B t$ toxins. But these are susceptible to lectin toxicity conferred by lectin genes 
which can be potentially exploited to develop insect resistant transgenic plants. About 50\% reduction in survival of brown plant hopper (Nilaparvata lugens) and other hemipteran pests could be achieved through expression of the Man-specific snowdrop lectin (GNA) in transgenic rice plants using constitutive or phloem-specific promo$\operatorname{ters}^{56,57}$.

\section{Nematodal bacteria}

Symbiotic enterobacteria present in nematodes of Heterorhabditis species offer a small-scale biological control of insect pests. These nematodes with bacterial cells in their gut release bacteria into the insect circulatory system. The bacterial toxins inside the insect circulatory system cause cell death in the insect host. A large number of insecticidal components have been investigated in the bacterium Photorhabdus luminescens ${ }^{58}$. A compound, cholesterol oxidase released by such bacteria exhibit insecticidal activity similar to $B t$ toxins through membrane destabilization.

\section{Secondary metabolites}

By-products of some metabolic pathways in transgenic plants have been found to exhibit toxic properties against pest species. For example, coding sequence fused to a chloroplast-targeting peptide or expression constructs containing part or all of the coding sequence of the protein, resulted in production of toxic active enzyme in transgenic tobacco ${ }^{59}$. Alkaloid caffeine produced in tobacco by the introduction of three genes encoding $\mathrm{N}$ methyl transferases is another example of a by-product of secondary metabolite with toxicity to pests in transgenic tobacco $^{60}$.

\section{Volatiles}

Plants are known to emit volatiles with properties of inhibiting pests. Such volatiles are known to be synthesized by RNA interference (RNAi)-mediated suppression of a cytP450 oxidase gene expressed in tobacco and Arabidopsis by constitutive overexpression of a plastid dual linalool/nerolidol synthase ${ }^{61,62}$. These volatiles may be used as attractants for predators and parasitoids. For example, transgenic plants of Arabidopsis having maize terpene synthase gene TPS10 emitted the sesquiterpene volatiles which attracted parasitoid wasps that attack maize pests ${ }^{63}$. Another example of volatile employed in pest control can be coated with sesquiterpene (E)- $\beta$ farnesene used by insects to communicate with each other and can be used as an alarm pheromone in aphids for attracting aphid predators and parasitoids ${ }^{64}$. Arabidopsis containing (E)- $\beta$-farnesene synthase gene from mint
(Mentha piperita) exhibited significant levels of aphid deterrence and also acted as the chosen attractant to the aphid parasitoid Diaeretiella rapae.

\section{RNAi and its complementing techniques}

RNA applications made revolution in the field of crop protection due to their environmentally friendly approach. RNA interference (RNAi) utilizes the plant's natural process for mediating management of pest control and is emerging as an alternative to chemical spray ${ }^{65,66}$. The RNA-based active ingredients will be used for biocontrol in the near future. This depends upon the quality of double stranded RNA (dsRNA), its stability and large scale production $^{65}$. Also, modification of an organism's genome is possible by employing genome-editing tool ${ }^{67}$. One such tool based upon CRISPR/Cas9 systems has been utilized for modification of susceptibility genes in agricultural crops to enhance resistance to crop pests ${ }^{68}$.

Furthermore, RNAi has emerged as a well-established technique of disrupting gene function in insect genome based on delivery by injection into insect cells or tissues. Partial resistance to insect pests can also be achieved by reducing the level of gene expression, measured by mRNA level, when fed to insects ${ }^{69}$. This led to the development of transgenic plants producing dsRNAs in transgenic maize corn rootworm by suppressing mRNA in the insect, reducing feeding damage compared to controls ${ }^{70}$. Similarly, in transgenic tobacco and Arabidopsis ${ }^{71}$, dsRNA directed against a detoxification enzyme (Cyt P450 gene CYP6AE14) for gossypol in cotton bollworm caused the insect to become more sensitive to gossypol in the diet.

To foster a healthier environment in modern agriculture, it has been advocated that plant viral defense strategies with the new revolutionary tools such as RNAi silencing, ZFN, TALENS, SmART and CRISPR/Cas9 have to be used to manage viral diseases. Several new viruses belonging to Poty, Cucumo, Illar, Gemini, Tospo and other groups ${ }^{72}$ have been identified in agricultural crops. Polymerase chain reaction (PCR) based techniques as well as Real-time PCR have been successfully used for detection of virus strains and their variants in various crops. Understanding molecular interaction between viruses and the resistant and susceptible plants leading to resistance or pathogenesis is the need of the hour, which has to be pursued by employing genetic engineering techniques and functional genomics. Apart from this, factors contributing to upsurge of polyphagous vectors like whitefly need to be understood which involve mixed cropping pattern, overlapping host range, suitable weather which supports the survival and prevalence of whitefly. Also, recombination is one of the genetic events which foster the evolution of diverse strains of whitefly in India $^{73}$. 


\section{Nanotechnological innovations}

The side effects of chemical pesticides caused by their poisonous components like heavy metals and non-biodegradable constituents necessitate searching safer alternatives for environmental friendly plant protection. Nano-based antimicrobials offer the best potential in this context. The nanopesticide is a formulation that is characterized with (a) Entities in the nanometer size range (up to $100 \mathrm{~nm}$ ), (b) Designated nano prefix (e.g. nanohybrid, nanocomposite) and/or (c) Novel properties associated with small size. A wide variety of nanoproducts employed to protect from diseases/pests have been described in detail by European Commission Joint Research Centre ${ }^{74}$. In the field of plant protection, nanopesticides involving organic ingredients, polymer-based inorganic silica, titanium dioxide, nanoemulsions and nanoclays in various forms (e.g. particles, micelles) have been evaluated and applied $^{75}$. Application of nano-pesticides is still in the incipient stages. However, nanosized silica silver ( $\mathrm{Si}-\mathrm{Ag})$ particles have been successfully used for controlling fungal pathogens, viz. Pythium ultimum, Magnaporthe grisea, Botrytis cinerea, Colletotrichum gleosporioides, Rhizoctonia solani and also bacterial pathogens such as Xanthomonas campestris. Similarly, iron nanoparticles coated with carbon have been used for treating localized infections in plants. A nano-based product 'Nano-Gro' has been launched as plant growth regulator and immunity enhancer. Another product 'Nano-5' is also available in the market as natural mucilage organic solution for controlling several plant pathogens and pests.

\section{Endophytes in plant protection}

Endophytic microbes, mostly bacteria and fungi live inside the plants and provide protection against pathogen attack and enhance tolerance to abiotic stresses also. Usage of endophytes in plant protection significantly reduces the usage of agricultural chemicals ${ }^{76}$. Endophytes have been reported to induce systemic acquired resistance (SAR) against a variety of pathogens by triggering metabolic pathways in host leading to synthesis of phytohormones, viz. salicylic acid, jasmonic acid and ethylene, leading to the formation of infection barriers and antimicrobial substances in plants. These microbes are also used as biocontrol agents in plant protection, as they restrict the growth of pathogens by producing a range of bioactive metabolites, hydrolytic enzymes, antibiotics and lipopeptides ${ }^{77-79}$. Endophytes promise an eco-friendly and viable option as biocontrol agents and may thus contribute potentially to sustainable agriculture.

\section{Strengthening quarantine services}

Government quarantine system offers services which are beyond the capabilities of individual beneficiaries due to cost factor. But in real sense, plant quarantine is supposed to serve at national level by creating barriers to the introduction of exotic pests and pathogens and also prevent their further spread. Quarantine measures can be successfully implemented with the active support of administrators, general public, farmers, scientists, communication media, customs and other stakeholders involved in the farm sector ${ }^{80}$. Subsequently, an effective quarantine system depends on several important pre-requisite data such as updated lists of endemic pests, authentic data on country-wide survey and surveillance, as well as current literature, which are also vital in implementing the PRA procedures. Further, to achieve an effective output of quarantine processing and biosecurity measures, it is essential to synchronize the plant quarantine system with the global plant quarantine system standards ${ }^{41}$.

\section{Conclusions}

Plant health needs to be viewed as an important perspective of measures to ensure food security which involves a multidisciplinary approach, reforms in human resources, natural resource management, agricultural research, rural infrastructure, etc. In this context, contriving novel mitigation measures of biotic stresses in farming sector by revamping the inadequacies of the ongoing national programmes for assuring national food and nutrition security menaced by viciously vibrant pests/pathogens due to climate change, mutations, invasions, etc. is the need of the hour. Various priority research areas for future work include novel measures for deciphering basic/molecular mechanism of host-pathogen/pest interactions, nanotechnology in pest and disease management, fumigants, volatile and acoustic techniques for stored grains, postharvest and vertebrate pest management, utilizing gene editing technologies such as CRISPR/Cas9 for strengthening transgenic resistant crops. Research should also supplement aspects of tritrophic pheromone/kairomone studies, identification of broad spectrum resistance, utilizing wild species gene pool for durable resistance, deployment of remote sensing technology and other artificial intelligence based measures for pest management, development of disease/pest prediction models, determination of factors leading to evolution of pests and pathogens, minimizing the effects of climate change on aggravation of biotic stresses of plants, innovative weed management, vertebrate pest control, etc.

Conflicts of interest: Authors declare no conflict of interest.

1. Rathee, M. and Dalal, P., Emerging insect pests in Indian Agriculture. Indian J. Ent., 2018, 80(2), 267-281.

2. Hill, D. S., Pest definitions. In The Economic Importance of Insects, Springer, Dordrecht, The Netherlands, 1997; https://doi.org/10.1007/978-94-011-5348-5_3. 
3. Udikeri, S. S., Kranthi, K. R., Patil, S. B., Modagi, S. A. and Vandal, N. B., Bionomics of mirid bug, Creontiades biseratense (Distant) and oviposition pattern in Bt cotton. Karnataka $\mathrm{J}$. Agric. Sci., 2010, 23(1), 153-156.

4. Halder, J., Rai, A. B. and Kodandaram, M. H., Compatability of neem oil and different entomopathogens for the management of major vegetable sucking pests. Natl. Acad. Sci. Lett., 2013, 36(1), 19-25.

5. Murali Baskaran, R. K. et al., National Status of Biotic Stress of Crops, ICAR-National Institute of Biotic Stress Management, Raipur, Chhattisgarh, India, 2018, p. 174 (ISBN: 978-81-9427881-8).

6. Mallikarjuna, J., Yele, Y. and Jain, S. K., Heavy infestation of sugarcane leafhopper, Pyrilla perpusilla on wheat and oats in Chhattisgarh. Indian J. Ent., 2019, 81(3), 516-517.

7. Kanakala, S. and Ghanim, M., Global genetic diversity and geographical distribution of Bemisia tabaci and its bacterial endosymbionts. PLoS ONE, 2019, 14(3), e0213946.

8. Singh, S., Pandey, A. K., Singh, B. K. and Rajak, D. C., Impact of exotic pests on agro-biodiversity and their management: a review. Biol. Bull., 2016, 2(1), 58-73.

9. Gupta, N., Verma, S. C., Sharma, P. L., Thakur, M., Sharma, P. and Devi, D., Status of invasive insect pests of India and their natural enemies. J. Entomol. Zool. Stud., 2019, 7(1), 482-489.

10. Naveena, N. L., Shashank, P. R., Devaramane, R. and Mallikarjuna, J., Invasive insect pests in India: current scenario and future perspective. Indian Entomol., 2020, 1(1), 23-31.

11. Biondi, A., Guedes, R. and Wan, F., Ecology, worldwide spread, and management of the invasive South American tomato pinworm, Tuta absoluta: past, present, and future. Annu. Rev. Entomol., 2018, 63, 239-258.

12. Urbaneja, A., Vercher, R., Navarro, V., Porcuna, J. L. and García-Marí, F., La polilla deltomate, Tuta absoluta. PHYTOMASpain, 2007, 194, 16-24.

13. Tropea-Garzia, G., Siscaro, G., Biondi, A. and Zappala, L., Biology, distribution and damage of Tuta absoluta, an exotic invasive pest from South America. Bull. OEPP, 2012, 42, 205-210.

14. Cannon, R. L., Matthews, D. and Collins, A review of the pest status and control options for Thrips palmi. Crop Prot., 2007, 26, 1089-1098.

15. Sharanabasappa, D. et al., First report of the fall Armyworm, Spodoptera frugiperda (J. E. Smith) (Lepidoptera, Noctuidae), an alien invasive pest on maize in India. Pest Manage. Hortic. Ecosyst., 2018, 24(1), 23-29.

16. Shrestha, S., Effects of climate change in agricultural insect pest. Acta Sci. Agric., 2019, 3(12), 74-80.

17. Manikandan, N., Kennedy, J. S. and Geethalakshmi, V., Effect of elevated temperature on development time of rice yellow stem borer. Indian J. Sci. Technol., 2013, 6(12), 5563-5566.

18. Srinivasa Rao, M., Manimanjari, D., Rama Rao, A. C., Swathi, P. and Maheswari, M., Effect of climate change on Spodoptera litura Fab. on peanut: a life table approach. Crop Prot., 2014, 66 , 98-106.

19. Srinivasa Rao, M. et al., Tritrophic interactions of cowpea [Vigna unguiculata subsp unguiculata (L.)], aphids [Aphis craccivora (Koch)] and Coccinellids [Menochilus sexmaculatus (Fab.)] under $\mathrm{eCO}_{2}$ and eTemp. J. Asia-Pacific Entomol., 2018, 21, 531537.

20. Gould, F., Brown, Z. S. and Kuzma, J., Wicked evolution: can we address the sociobiological dilemma of pesticide resistance? Science, 2018, 360, 728-732.

21. Sarwar, M. and Salman, M., Insecticides resistance in insect pests or vectors and development of novel strategies to combat its evolution. Int. J. Bioinform. Biomed. Eng., 2015, 1(3), 344-351.

22. Kole, R. K., Roy, K., Panja, B. N., Sankarganesh, E., Mandal, T. and Worede, E., Use of pesticides in agriculture and emergence of resistant pests. Indian J. Anim. Health, 2020, 58(2), 53-70.
23. Kranthi, K. R., Bt cotton Questions and Answers. Indian Society for Cotton Improvement, Mumbai, 2012, pp. 1-70.

24. Laha, G. S. et al., Changes in Rice disease scenario in India: An analysis from production oriented survey. Technical Bulletin No. 91, ICAR-IIRR, Hyderabad, India, 2017, p. 95.

25. Nagarajan, S., Climate change and cereal diseases in south Asia In Wheat, Productivity Enhancement under Changing Climate (eds Singh, S. S. et al.), Narosa Publishing House Pvt Ltd, New Delhi, India, 2012, pp. 218-226.

26. Chhabra, M. L., Parameswari, B. and Viswanathan, R., Pathogenic behaviour pattern of Colletotrichum falcatum isolates of sugarcane in sub-tropical India. Vegetos, 2016, 29, 1-4.

27. Thangavelu, R., Mostert, D., Gopi, M., Ganga Devi, P., Padmanaban, B., Molina, A. B. and Viljoen, A., First detection of Fusarium oxysporum f. sp. cubense tropical race 4 (TR4) on Cavendish banana in India. Eur. J. Plant Pathol., 2019, 154, 777-786.

28. Pande, S. and Sharma, M., Climate Change: potential impact on chickpea and pigeonpea diseases in the rainfed semi-arid tropics (SAT). In Proceedings of the 5th International Food Legume Research Conference on Grain Legumes (AEP VII), Antalya, Turkey, 2010.

29. Sharma, M., Mangala, U. N., Krishnamurthy, M., Vadez, V. and Pande, S., Drought and dry root of chickpea. In Proceedings of the 5th International Food Legume Research Conference on Grain Legumes (AEP VII), Antalya, Turkey, 2010.

30. Gautam, H. R., Bhardwaj, M. L. and Kumar, R., Climate change and its impact on plant diseases. Curr. Sci., 2013, 105, 16861691.

31. Bishnoi, S. K., Kumar, S. and Singh, G. P., Wheat blast readiness of the Indian wheat sector. Curr. Sci., 2021, 120, 262-263.

32. https://www.downtoearth.org.in/blog/food/verifying-viral-virustruths-tomatoes-tiranga-and-trps-71720 (accessed on 25 January 2021).

33. Mandal, B., Rao, G. P., Baranwal, V. K. and Jain, R. K. (eds), Introduction: a century of plant virology in India. In $A$ Century of Plant Virology in India, Springer, Singapore, 2017; https://doi. org/10.1007/978-981-10-5672-7_1.

34. Verma, R., Ram, R. D. and Tomer, S. P. S., Survey and surveillance of Papaya ring spot virus disease in India. J. Maharashtra Agric. Univ., 2007, 32, 277-278.

35. Sahu, B. et al., Begomoviruses affecting pulse and vegetable crops are unevenly distributed in distinct agroecological zones of eastern India. J. Phytopathol., 2021; doi:10.1111/jph.12978.

36. Walia, R. K. and Chakrabarti, P. K. (eds), Nematode problems of crops in India. ICAR-All India Coordinated Research project on Nematodes in Agriculture, 2018, p. 400.

37. Pimentel, D., Lach, L., Zuniga, R. and Morrison, D., Environmental and economic costs of non-indigenous species in the United States. BioScience, 2000, 50, 53-65.

38. Mishra, J. S., Moorthy, B. T. S., Bhan, M. and Yadurajy, N. T., Relative tolerance of rainy season crops to field dodder (Cuscuta campestris) and its management in niger (Guizotia abyssinica). Crop Prot., 2007, 26(4), 625-629.

39. Mishra, J. S., Biology and management of Cuscuta spp. Indian J. Weed Sci., 2009, 41(1\&2), 1-11.

40. Phool Chand, Singh, A., Vishwakarma, R. and Singh, S. K., Plant quarantine: an effective approach for prevention of alien pest and disease. Bull. Environ. Pharmacol. Life Sci., 2017, 6(11), 8-13.

41. Ghosh, S., Lockdown throws up challenges for quarantine of plant samples for research; https://india.mongabay.com (accessed on 20 January 2021).

42. Meena, R. P., Meena, B. L., Nandal, U. and Meena, C. L., Indigenous measures developed by farmers to curb the menace of blue bull (Boselaphus tragocamelus) in district Rajsamand, Rajasthan, India. Indian J. Tradit. Know., 2014, 13(1), 208-215. 
43. Nasim, A. A., Status of mammals with special reference to population estimation of Nilgai Boselaphus tragocamelus and suggest mitigation measures to prevent crop damage in and around Surajpur reserve forest, Uttar Pradesh, India. J. Entomol. Zool. Stud., 2017, 5(4), 1085-1091.

44. Tisdel, C. A., Wild Pigs Environmental Pest or Economic Resource? Pergamon Press Ltd, Oxford, UK, 1982.

45. Roberts, T. J., The Mammals of Pakistan, Ernest Benn, London, 1977, pp. 1-361.

46. Groot-Bruinderinck, G. W. T. A., Hazebrook, E. and Van Der Voot, H., Diet and condition of wild boar (Sus scrofa) without supplementary feeding. J. Zool. Soc. London, 1994, 233, 631648 .

47. Moreira, J., Rosa, L., Lourenço, J., Barroso, I., Pimenta, V., Projec to Lobo; Report of Progress, 1996 (Co-financed by the EU - Life Program). Ministry of Environment and Natural Resources; Institute for Conservation of Nature. Montesinho Natural Park, Bragança (Portugal). 61, (1997).

48. Khokhar, A. R. and Rizvi, S. W. A., Productivity enhancement of rice crop yield through prevention of losses due to wild boars in Pakistan. Turk. J. Zool., 1998, 22, 167-171.

49. Vasudeva Rao, V., Naresh, B., Ravinder Reddy, V., Sudhakar, C., Venkateswarlu, P. and Rama Rao, D., Traditional management methods used to minimize wild boar (Sus scrofa) damage in different agricultural crops at Telangana state, India. Int. J. Multidiscip. Res. Dev., 2015, 2(2), 32-36.

50. Kumar, A., Traditional plant protection management practices of Rajasthan. LEISA India, 2007, 29-30.

51. Toenniessen, G. H., O'Toole, J. C. and DeVries, J., Advances in plant biotechnology and its adoption in developing countries. Curr. Opin. Plant Biol., 2003, 6, 191-198.

52. Brookes, G. and Barfoot, P., GM crops: the global economic and environmental impact: the first nine years 1996-2004. AgBioForum, 2005, 8, 15.

53. Stewart, S. D., Adamczyk, J. J., Knighten, K. S. and Davis, F. M., Impact of Bt cottons expressing one or two insecticidal proteins of Bacillus thuringiensis Berliner on growth and survival of noctuid (Lepidoptera) larvae. J. Econ. Entomol., 2001, 94, 752760 .

54. Chitkowski, R. L., Turnipseed, S. G., Sullivan, M. J. and Bridges, W. C., Field and laboratory evaluations of transgenic cottons expressing one or two Bacillus thuringiensis var. kurstaki Berliner proteins for management of noctuid (Lepidoptera) pests J. Econ. Entomol., 2003, 96, 755-762.

55. Rajamohan, F., Alzate, O., Cotrill, J. A., Curtiss, A. and Dean, D. H., Protein engineering of Bacillus thuringiensis deltaendotoxin: mutations at domain II of CryIAb enhance receptor affinity and toxicity toward gypsy moth larvae. Proc. Natl. Acad. Sci. USA, 1996, 93, 14338-14343.

56. Rao, K. V. et al., Expression of snowdrop lectin (GNA) in transgenic rice plants confers resistance to rice brown plant hopper. Plant J., 1998, 15, 469-477.

57. Foissac, X., Loc, N. T., Christou, P., Gatehouse, A. M. R. and Gatehouse, J. A., Resistance to green leafhopper (Nephotettix virescens) and brown planthopper (Nilaparvata lugens) in transgenic rice expressing snowdrop lectin (Galanthus nivalis agglutinin; GNA). J. Insect Physiol., 2000, 46, 573-583.

58. French-Constant, R. H., Dowling, A. and Waterfield, N. R., Insecticidal toxins from Photorhabdus bacteria and their potential use in agriculture. Toxicon, 2007, 49, 436-451.

59. Corbin, D. R., Gerenuk, R. J., Ohnmeiss, T. E., Greenplate, J. T. and Purcell, J. P., Expression and chloroplast targeting of cholesterol oxidase in transgenic tobacco plants. Plant Physiol., 2001, 126, 1116-1128.

60. Kim, Y. S., Uefuji, H., Ogita, S. and Sano, H., Transgenic tobacco plants producing caffeine: a potential new strategy for insect pest control. Transgenic Res., 2006, 15, 667-672.
61. Wang, E., Wang, R., De Parasis, J., Loughrin, J. H., Gan, S. and Wagner, G. J., Suppression of a P450 hydroxylase gene in plant trichome glands enhances natural-product-based aphid resistance. Nat. Biotechnol., 2001, 19, 371-374.

62. Aharoni, A. et al., Terpenoid metabolism in wild-type and transgenic Arabidopsis plants. Plant Cell, 2003, 15, 2866.

63. Schnee, C., Kollner, T. G., Held, M., Turlings, T. C. J., Gershenzon, J. and Degenhardt, J., The products of a single maize sesquiterpene synthase form a volatile defense signal that attracts natural enemies of maize herbivores. Proc. Natl. Acad. Sci. USA, 2006, 103, 1129-1134.

64. Beale, M. H. et al., Aphid alarm pheromone produced by transgenic plants affects aphid and parasitoid behavior. Proc. Natl. Acad. Sci. USA, 2006, 103, 10509-10513.

65. Niehl, A., Soininen, M., Poranen, M. M. and Heinlein, M., Synthetic biology approach for plant protection using dsRNA. Plant Biotechnol. J., 2018, 16(9), 1679-1687.

66. Bramlett, M., Plaetinck, G. and Maienfisch, P., RNA-based biocontrols - a new paradigm in crop protection. Engineering, 2020, 6, 522-527.

67. Zhang, Y., Massel, K., Godwin, I. D. and Gao, C., Applications and potential of genome editing in crop improvement. Genome Biol., 2018, 19, 210.

68. Borrelli, V., Brambilla, V., Rogowsky, P., Marocco, A. and Lanubile, A., The enhancement of plant disease resistance using CRISPR/Cas9 technology. Front. Plant Sci., 2018, 9, 1245.

69. Turner, C. T., Davy, M. W., MacDiarmid, R. M., Plummer, K. M., Birch, N. P. and Newcomb, R. D., RNA interference in the light brown apple moth, Epiphyas postvittana (Walker) induced by double-stranded RNA feeding. Insect Mol. Biol., 2006, 15, 383-391.

70. Baum, J. A. et al., Control of coleopteran insect pests through RNA interference. Nat. Biotechnol., 2007, 25, 1322-1326.

71. Mao, Y. B. et al., Silencing a cotton bollworm P450 monoxygenase gene by plant-mediated RNAi impairs larval tolerance of gossypol. Nat. Biotechnol., 2007, 25, 1307-1313.

72. Rishi, N., Significant plant virus diseases in India and a glimpse of modern disease management technology. J. Gen. Plant Pathol., 2009, 75, 1-18.

73. Varma, A. and Malathi, V. G., Emerging geminivirus problems: a serious threat to crop production. Ann. Appl. Biol., 2003, 142, $145-164$

74. European Commission Joint Research Center, Reference report considerations on a definition of nanomaterial for regulatory purposes, 2010.

75. Matthews, G. A., Pests, pesticides and pest management. In Highlights in Environment Research (ed. Mason, J.), Imperial College Press, London, 2000, pp. 165-189.

76. White, J. F. et al., Review: endophytic microbes and their potential applications in crop management. Pest Manag. Sci., 2019, 75, 2558-2565.

77. Hardoim, P. R. et al., The hidden world within plants: ecological and evolutionary considerations for defining functioning of microbial endophytes. Microbiol. Mol. Biol. Rev., 2015, 79, 293-320.

78. De-Silva, N. I., Brooks, S., Lumyong, S. and Hyde, K. D., Use of endophytes as biocontrol agents. Fungal Biol. Rev., 2019, 33, 133-148.

79. Kumar, V., Jain, L., Jain, S. K., Chaturvedi, S. and Kaushal, P., Bacterial endophytes of rice (Oryza sativa L.) and their potential for plant growth promotion and antagonistic activities. S. Afr. J. Bot., 2020, 34, 50-63.

80. Mathys, G., Thoughts on quarantine problems. EPPO. Bull. OEPP, 1975, 5(2), 55.

81. Prakash, A. et al., Emerging pest scenario in rice in India. $J$. Appl. Zool. Res., 2014, 25(2), 179-181.

82. ICAR, Status paper-Crop Protection. Division of Crops Science, ICAR, Krishi Bhawan, New Delhi, 2018. 
83. Arora, R. and Dhawan, A. K., Climate change and insect pest management. In Recent Trends in Integrated Pest Management. Invited Papers - Third Congress on Insect Science (eds Dhawan, K. et al.), Indian Society for the Advancement of Insect Science, Punjab Agricultural University, Ludhiana, 18-20 April 2011, pp. 77-88.

84. Kaur, S., Dhaliwal, L. and Kaur, P., Impact of climate change on wheat disease scenario in Punjab. J. Res., 2008, 45(3\&4), 161170 .

85. Deole, S. and Paul, N., First report of fall army worm, Spodoptera frugiperda (J. E. Smith), their natural of damage and biology on maize crop at Raipur, Chhattisgarh. J. Entomol. Zool. Stud., 2018, 6(6), 219-221.

86. Pande, S., Desai, S. and Sharma, M., Impacts of climate change on rainfed crop diseases: Current status and future research needs. National Symposium on Climate Change and Rainfed Agriculture, Central Research Institute of Dryland Agriculture, Hyderabad, 18-20 February 2010, pp. 55-59.

87. Singh, H. S. et al., Emerging pests of fruit crops like mango, litchi, bael, tamarind, sweet orange, banana, papaya and guava in Eastern India. J. Appl. Zool. Res., 2014, 25(2), 161-169.

88. Kanhar, K. A., Sahito, H. A., Kanher, F. M., Tunio, S. A. and Awan, R. R. H., Damage per cent and biological parameters of leaf miner, Acerocercops syngramma (Meyrick) on different mango varieties. J. Entomol. Zool. Stud., 2016, 4(4), 541-546.

89. Gundappa, Jayanthi, P. D. K. and Verghese, A., Management of spiraling whitefly, Aleurodicus disperses (Russel) in guava, Psidium guajava L. Pest Manage. Hortic. Ecosyst., 2013, 19(1), 102-105.

90. Jayanthi, P. D. K. and Verghese, A., Sapodilla seed borer, Trymalitis margaritas Meyrick - an invasive or indigenous species. Pest Manage. Hortic. Ecosyst., 2010, 16(2), 141-147.

91. Dadmal, S. M. and Pawar, N. P., The fruit sucking moth, Eudocima (Othreis) fullonica on Nagpur mandarin in Vidarbha Region. Insect Environ., 2001, 6, 167.

92. Singh, S. and Kaur, G., Incidence of metallic shield bug, Scutellera perplexa (Westwood) ( $S$. nobilis Fabricius) on grape in Punjab. Pest Manage. Hortic. Ecosyst., 2015, 21(1), 90-94.

93. Jayanthi, P. D. K., Nagaraja, T., Raghava, T. and Kempraj, V., Pomegranate, a newly documented host plant of tea mosquito bug, Helopeltis antonii Signoret. Pest Manage. Hortic. Ecosyst. 2016, 22(1), 88-90.

94. Jayanthi, P. D. K., Reddy, P. V. R., Kempraj, V. and Shashank, P. R., Outbreak of banana skipper, Erionota torus Evans (Lepidoptera: Hesperiidae) in sourhtern India: evidence of expanded geographic range. Pest Manage. Hortic. Ecosyst., 2015, 21(1), 95-97.

95. Kumar, V., Kumar, A. and Nath, V., Emerging pests and diseases of litchi (Litchi chinensis Sonn.). Pest Manage. Hortic. Ecosyst., 2011, 17, 10.

96. Rai, A. B., Halder, J. and Kodandaram, Emerging insect pest problems in vegetable crops and their management in India: an appraisal. Pest Manage. Hortic. Ecosyst., 2014, 20(2), 113122.

97. Ranganath, H. R., Naveena, N. L., Saroja, S. and Yeshwanth, H. M., Mirid bug, Nesidiocoris cruentatus (Ballard) - an emerging pest on bottle gourd, Lagenaria siceraria (Molina) Standley. Pest Manage. Hortic. Ecosyst., 2015, 21(1), 104-105.

98. Singh, J. and Raghuraman, M., Emerging scenario of important mite pests in North India. Zoosymposia, 2011, 6, 170-179.
99. Joshi, M. D., Butani, P. G., Patel, V. N. and Jeyakumar, P., Cotton mealybug, Phenococcus solenopsis Tinsley - a review. Agric. Rev., 2010, 31(2), 113-119.

100. Shylesha, A. N., Jalali, S. K., Gupta, A., Varshney, R., Venkatesan, T. and Shetty, P., Studies on new invasive pest, Spodoptera frugiperda (J. E. Smith) (Lepidoptera: Noctuidae) and its natural enemies. J. Biol. Control, 2018, 32(3), 1-7.

101. Prashar, M., Bhardwaj, S. C., Jain, S. K. and Datta, D., Pathotypic evolution in Puccinia striiformis in India during 1995-2004. Aust. J. Agric. Res., 2007, 58, 602-604.

102. Mishra, S. C., The American blight or wooly apple aphid, E. lanigerum (Hausmann). Agric. J. India, 1920, 15, 627.

103. Jhala, R. C., Bharpoda, T. M. and Patel, M. G., Phenococcus solenopsis Tinsely (Hemiptera: Pseudococcidae, the meal bug species recorded first time on cotton an its alternate host plants in Gujarat, India. Uttar Pradesh J. Zool., 2008, 28(3), 403-406.

104. Sujithra, M., Rajkumar, Prathibha, V. H., Vinayaka, H. and Poorani, J., Occurrence of nesting whitefly Paraleyrodes minei laccarino (Hemiptera: Aleyrodidae) in India. Indian J. Entomol., 2019, 81, 507-510

105. Singh, S. P., Some success stories in classical biological control of agriculture pest in India, Asia-Pacific Association of Agricultural Research Institutions, Bangkok, Thailand, 2004.

106. Fletcher, T. B., Some south Indian insects and other animals of importance considered especially from an economic point of view, Superintendent Government Press, Madras, 1914, p. 565.

107. Sridhar, V., Chakravarthy, A. K., Asokan, R. S., Vinesh, K., Rebijith, B. and Vennila, S., New record of the invasive South American tomato leaf miner, (Meyrick) (Lepidoptera: Gelechiidae) in India. Pest Manage. Hortic. Ecosyst., 2014, 20, 148-154.

108. Suganthy, M., Rageshwari, S., Senthilraja, C., Nakkeeran, S., Malathi, V. G., Ramaraju, K. and Renukadevi, P., New record of Western flower thrips, Frankliniella occidentalis (Pergande) (Thysanoptera: Thripidae) in South India. Int. J. Environ. Agric. Biotech., 2016, 1(4), 857-867.

109. Bisht, K. and Giri, G. S., Invasive insect pest scenario in India: A threat to biodiversity. J. Entomol. Res., 2019, 43(2), 229-234.

110. Palaniswami, M. S., Pillai, K. S., Nair, R. R. and Mohandas, C. A., A new cassava pest in India. Cassava Newslett., 1995, 19, 6-7.

111. Rao, N. B. V. C., Roshan, D. R., Rao, G. K. and Ramanandam, G. A., Review on rugose spiralling whitefly, Aleurodius rugioperculatus Martin (Hemiptera: Aleyrodidae) in India. J. Pharm. Phytol., 2018, 7(5), 948-953.

112. Selvaraj, K., Sundararaj, R. and Sumalatha, B. V., Invasion of the palm infesting whitefly, Aleurotrachelus atratus Hempel (Hemiptera: Aleyrodidae) in the Oriental region. Phytoparasitica, 2019, 47, 327-332; doi:10.1007/s12600-019-00742-1.

113. Nagrare, V. S., Kranthi, S., Biradar, V. K., Zade, N. N., Sangode, V. and Kakde, G., Widespread infestation of the exotic mealybug species, Penacoccus solenopsis (Tinsely) (Hemiptera: Pseudcoccid, on cotton in India. Bull. Entomol. Res., 2009, 99, 537-541.

114. Vega, R. E., Mercadier, G., Damon, A. and Krik, A., Natural enemies of the coffee berry borer, Hypothenemus hampei (Ferrari) (Coleoptera: Scolytidae) in Togo and Cote d'Ivoire, and other insects associated with coffee beans. Afr. Entomol., 1999, 7(2), $243-248$.

Received 24 December 2020; revised accepted 16 February 2021

doi: $10.18520 / \mathrm{cs} / \mathrm{v} 121 / \mathrm{i} 1 / 26-36$ 